$$
\begin{aligned}
& \text { ORNL-3511 } \\
& \text { UC-25 - Metals, Ceramics, and Materials } \\
& \text { TID }-4500 \text { (22nd ed.) }
\end{aligned}
$$

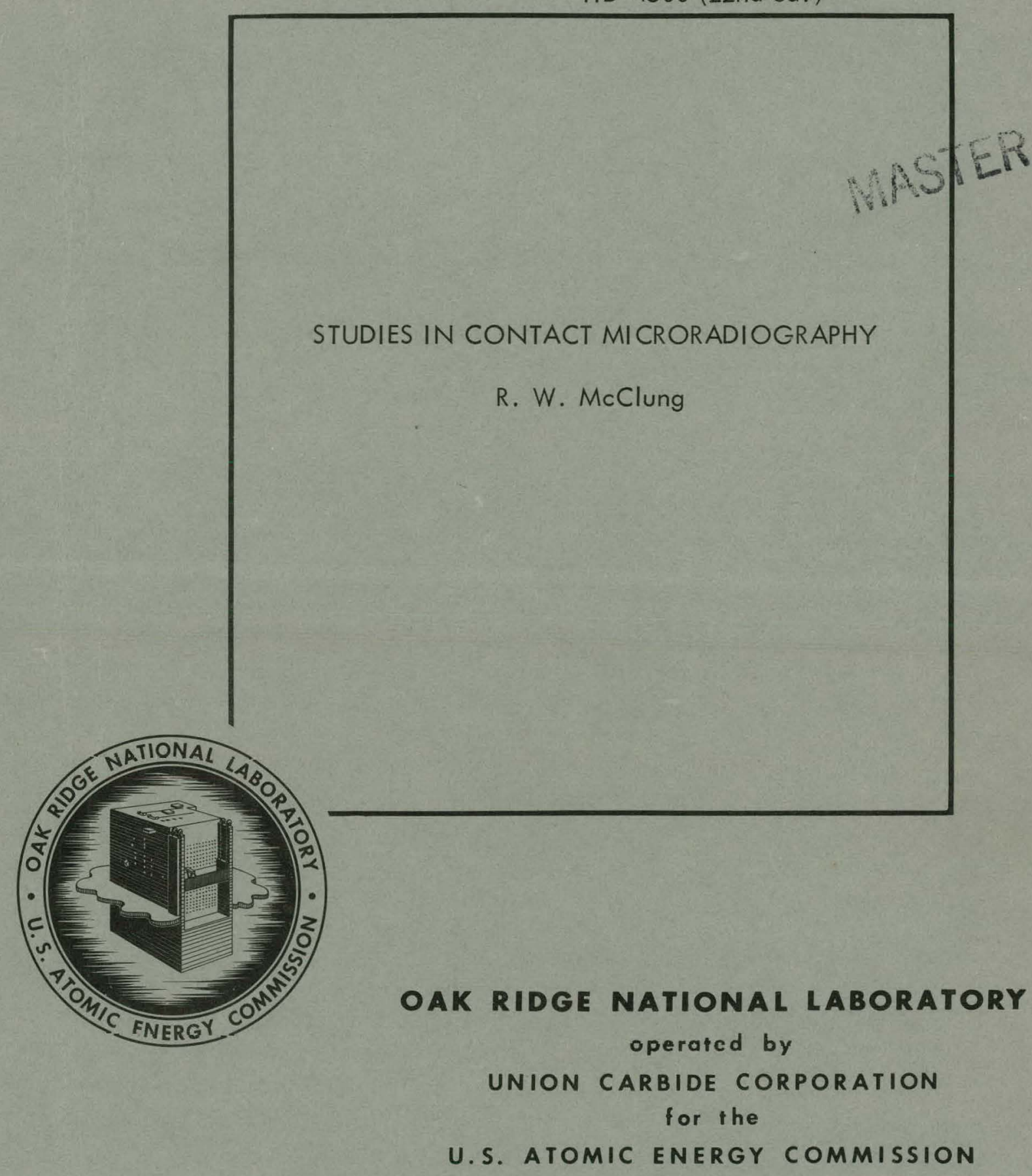




\section{DISCLAIMER}

This report was prepared as an account of work sponsored by an agency of the United States Government. Neither the United States Government nor any agency Thereof, nor any of their employees, makes any warranty, express or implied, or assumes any legal liability or responsibility for the accuracy, completeness, or usefulness of any information, apparatus, product, or process disclosed, or represents that its use would not infringe privately owned rights. Reference herein to any specific commercial product, process, or service by trade name, trademark, manufacturer, or otherwise does not necessarily constitute or imply its endorsement, recommendation, or favoring by the United States Government or any agency thereof. The views and opinions of authors expressed herein do not necessarily state or reflect those of the United States Government or any agency thereof. 


\section{DISCLAIMER}

Portions of this document may be illegible in electronic image products. Images are produced from the best available original document. 


\section{LEGAL NOTICE}

This report was prepared as an account of Government sponsored work. Neither the United States, nor the Commission, nor any person acting on behalf of the Commission:

A. Makes any warranty or representation, expressed or implied, with respect to the accuracy, completeness, or usefulness of the information contained in this report, or that the use of any information, apparatus, method, or process disclosed in this report may not infringe privately owned rights; or

B. Assumes any liabilities with respert to the use of, or for damuges resulting from the use of any information, apparatus, method, or process disclosed in this report.

As used in the above, "person acting on behalf of the Commission" includes any employee or contractor of the Commission, or employee of such contractor, to the extent that such employee or contractor of the Commission, or employee of such contractor prepares, disseminates, or provides access to, any information pursuant to his employment or contract with the Commission, or his employment with such contractor. 
Contract No. W-7405-eng-26

METALS AND CERAMICS DIVISION

STUDIES IN CONTACT MICRORADIOGRAPHY

R. W. MeClung

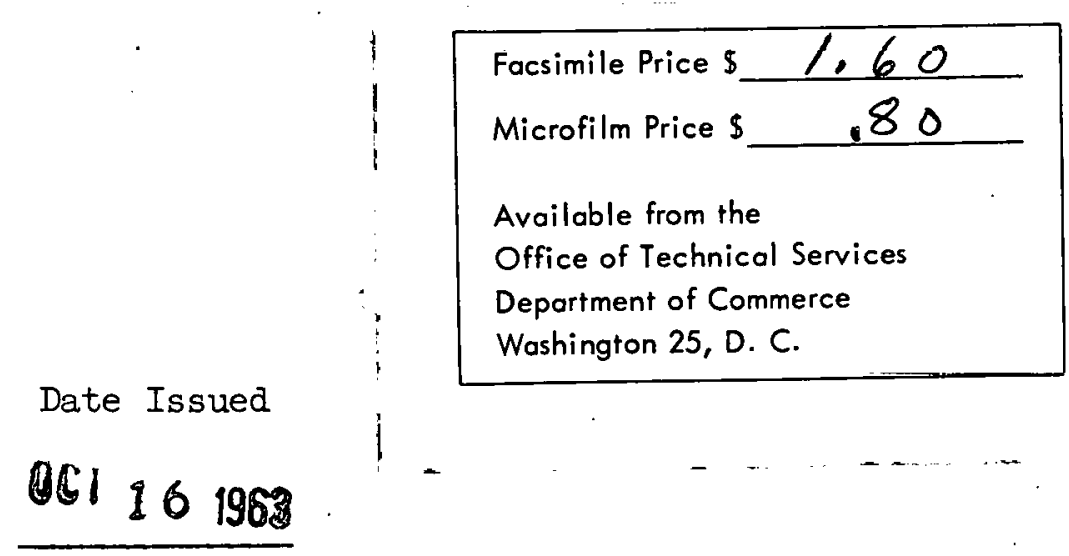
OAK RIDGE NATIONAL LABORATORY
Oak Ridge, Tennessee
operated by
UNION CARBIDE CORPORATION
for the

U. S. ATOMIC ENERCY COMMISSION 


\section{THIS PAGE}

\section{WAS INTENTIONALLY \\ LEFT BLANK}




\section{ABSTRACT}

Recent developments in techniques for low-voltage radiography have found application for the examination and evaluation of minute details in small or thin specimens. Utilization of $x$-ray tubes and helium chambers with thin windows for maximum transmission of soft $x$ rays and bare film with dark-room exposure techniques have allowed very high contrast radiographs to be produced on low-contrast materials.

These conditions, coupled with very high resolution photographlc emulsion detectors, have resulted in the observation of detail approximately $1 \mu$ in size. Useful examination of the plates and subsequent reproductions have been made at magnifications as high as 500X.

This contact system offers the advantage of evaluation of a relatively large area, as compared to the restricted field of observation of projection microradiography. Included among the subjects have been graphitecoated $\mathrm{UC}_{2}$ particles, graphite, beryllium, paper, and other organic specimens. 


\title{
Studies in Contact Microradiography
}

\author{
R. W. McClung \\ Metals and Ceramics Division \\ Oak Ridge National Laboratory* \\ Oak Ridge, Tennessee
}

\section{INIRODUCTION}

There is an increasing trend toward miniaturization of components and assemblies, particularly in the aerospace industries. Although not as widely recognized, miniaturization has become increasingly important in the nuclear power industry as well. The need has also increased markedly for microscopic evaluation of materials rather than or in addition to the macroscopic inspections which have been performed. Because of these factors, new nondestructive testing methods and techniques which are capable of revealing microscopic detail are being actively pursued by many organizations. One such program at the Oak Ridge National Laboratory (ORNL) has been a study of contact microradiographic techniques for the $x$-ray evaluation of tiny specimens or the investigation of selected small regions in large specimens. Earlier work in x-ray microscopy has been reportec: by Engstrom ${ }^{1}$ and Coslett. ${ }^{2}$ The program at ORNL was a continuation of a study on techniques for low-voltage radiography. ${ }^{3}$ A wide variety of materials and specimens have been examined ucing the microradiegraphis techniques with detail on the order of $1 \mu$ being observahlee.

\footnotetext{
* Operated by Union Carbide Corporation for the U. S. Atomic Energy Commission.
} 


\section{GENERAL PRINCIPLES}

The successful application of radiographic techniques to very small or very thin specimens requires considerable change from conventional practice. As radiation is transmitted through a specimen, the intensity will be decreased. This decrease is related to the specimen thickness and the energy-dependent absorption coefficient of the material. Variations in these values across a specimen create intensity gradients in the radiation beam profile which can be detected by a medium such as photographic film. For the thin specimens to be discussed in this paper, it has been necessary to use low energy irradiation to obtain an interpretable contrast resulting from variations in absorption.

\section{EQUIPMENT}

\section{$\mathrm{X}$-Ray Generation and Absorption}

Commercial radiographic instrumentation has been used in this program . with only minor modifications having been made to obtain better control of the x-ray energy and exposure time. The utilization of very low energy $x$ rays to obtain the ultimate in observable contrast makes the presence of absorbers other than the small specimen most undesirable. Extraneous "radiation thieves" not only degrade the quality of the radiograph, but also can make the exposure time impractical if not impossible. Several important steps have been taken to eliminate all unnecessary absorbers. The beryllium window in the $\mathrm{x}$-ray tube is only $0.008-i n$. thick as compared with a 0.040-in. thickness for the standard tubes. A helium 
chamber with a 0.0005-in.-thick polyethylene "window" has been used to displace the air between the x-ray source and the specimen. Bare-film darkroom exposure techniques permit the removal of the common lightopaque film holder. This low absorption system has permitted high-contrast images to be obtained on low-contrast materials and allowed the use of lower $\mathrm{x}$-ray energies which enhance the contrast even further.

\section{Radiation Detectors and Processing}

As the radiographs are viewed at high magnifications to observe the detail of interest, several fine-grained emulsions have been investigated during the studies of contact microradiography. A fine-grained industrial $x$-ray film has been successfully viewed at magnifications up to about $60 x$. The grain of the emulsion prevents the observation of any further detail at higher magnification. By using high resolution plates coated with an emulsion with a resolution capability of 15,000 lines per centimeter (38,000 lines/in.), practical magnifications up to 500x have been attained.

A number of fine-grained film-processing solutions were tested to determine the optimum for the microradiographic application. It was found that commercial $x$-ray developer gave results as good or better than any other fine grain developer and, because of its ready availability near the $\mathrm{x}$-ray equipment, has been used throughout the program. Since viewing is performed at high magnification on the processed plates, care must be taken to maintain the process solution as clean as possible. Any small particulate matter which might adhere to the surface could cause difficulty in the subsequent evaluation. 


\section{PROCEDURE}

As mentioned previously, the exposures were performed in a darkened room. The specimens were placed directly on the radiographic plate beneath the helium chamber as shown in Fig. 1. Because of the 1.5-mm focal spot size in the $x$-ray tube, the specimens should be as close to the detector as possible to minimize the geometric unsharpness. A target-to-film distance of 42 in. was normally used. Attention must be given to the mechanical stability of the plate stage, since any relative motion between the specimen and plate will cause a blurring of the image. This is of particular concern for spherical specimens and long exposure times. For instance, common specimens in our program have been spherical uranium-carbide particles which were coated with pyrolytic graphite. Although the particles were only about $0.010 \mathrm{in}$. in diameter, the exposure time was approximately $1 \mathrm{hr}$ and $15 \mathrm{~min}$.

Energy levels which have been used varied, in general, from 5 up to about $10 \mathrm{kvp}$. At the higher energy, the exposure times were only a few minutes for the fine-grained industrial $x$-ray film. However, the very thin emulsion of the high resolution plates has very slow response to the $x$ rays; consequently long exposure times are required. But the enhanced detail justifies the increased time. The fact that a large number of tiny specimens can be radiographed simultaneously further overcomes any objections to long exposures. With the equipment currently 


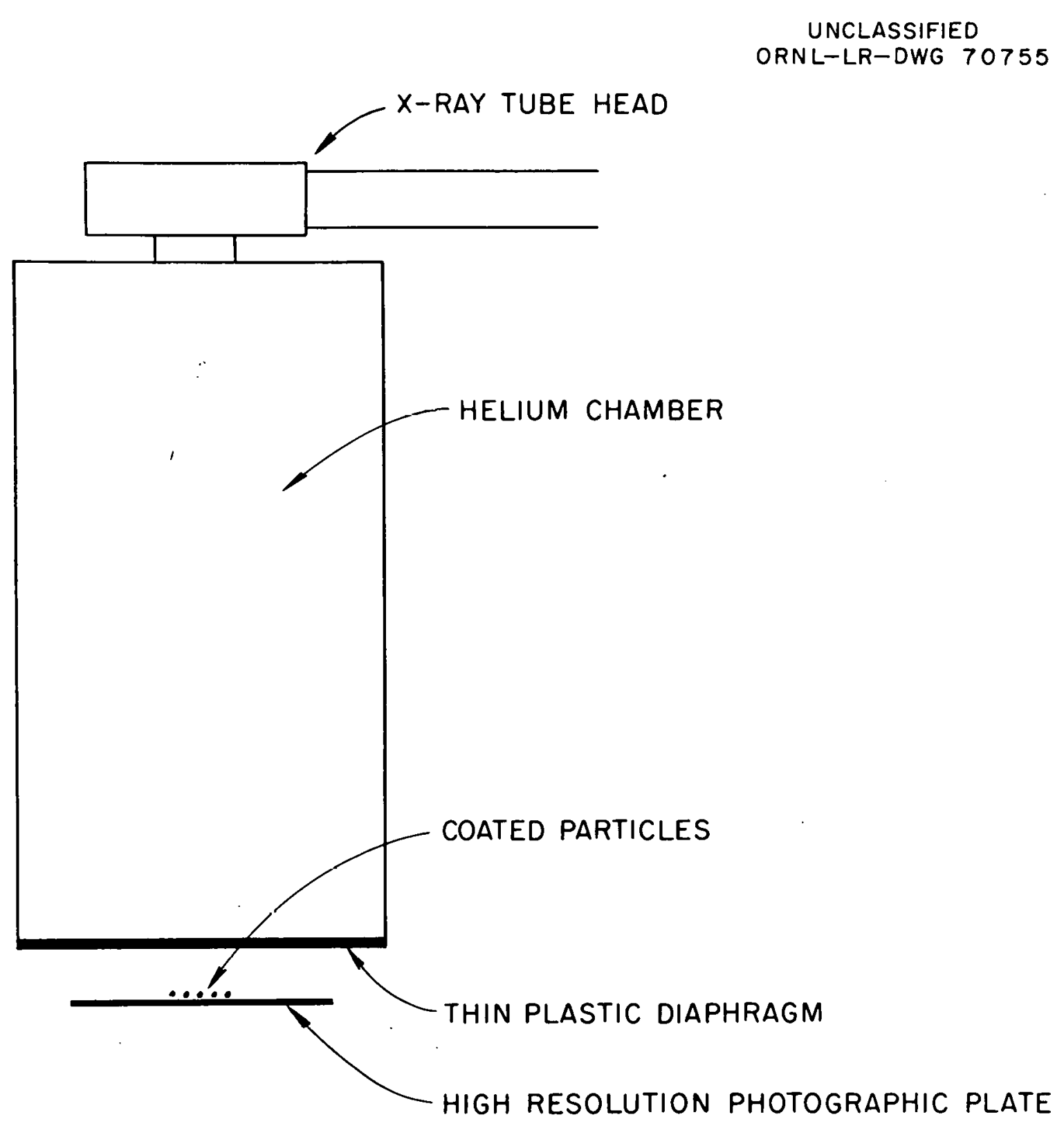

Fig. 1. Arrangement of Apparatus for Contact Microradiography 
being used, a useful irradiation area of about $10 \times 8$ in. is obtained which can, of course, accommodate a very large number of specimens.

For thin specimens and the very large $\frac{\text { source-to-specimen }}{\text { specimen-to-film }}$ ratio, a principal limitation on resolution or observable detail is the range of the photoelectron in the emulsion. At the low energies used, this was no more than $1 \mu .4$

To obtain the desired magnification, transmitted light microscopy is used for direct viewing and the subsequent preparation of photomicrographs.

\section{APPLICATION}

A frequent subject for microradiography has been spherical uranium carbide particles which were coated with a material such as pyrolytic graphite or alumina. These fuel particles seem to be very promising to the nuclear industry because of their high-temperature capabilities, inexpensive fabrication, and good neutron economy. 5, 6 Typical dimensions for such a specimen include a 0.006-in. core, 0.002-in. coating thickness, and a total diameter of 0.010 in. Figure 2 is a negative print of a contact microradiograph enlarged to $75 \mathrm{X}$. These selected particles demonstrate some of the characteristics which can be evaluated by this technique. Core diameter, coating thickness, and total diameter can be very accurately determined. As shown by the particles on the right and in the lower left corner of the figure, information on core integrity (or absence). can be easily obtained. The improper presence of fuel or 


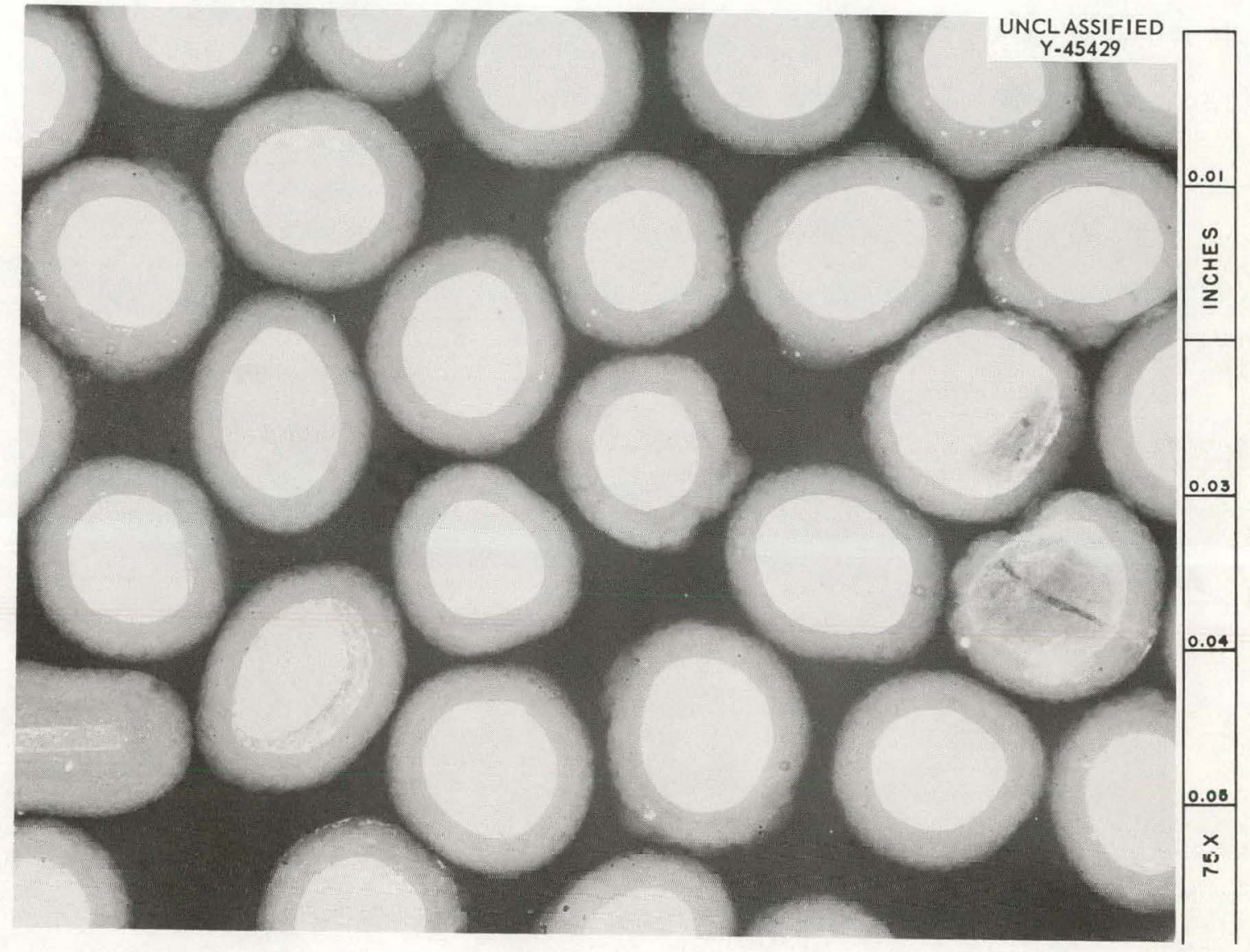

Fig. 2. Selected $\mathrm{UC}_{2}$ Particles Coated with Pyrolytic Graphite. 75X. 
other dense material in the annular coating is readily visible as white spots, areas, or rings and, with the proper orientation, cracks in faulty coatings may be detected.

Figure 3 is a 500X microradiograph of a thin 2000-mesh nickel screen. An optical photomicrograph of this screen compares exactly with the microradiograph. Although this object does not tax the system, it does graphically demonstrate the capabilities. The mesh specimen which was approximately $4 \times 5$ in. was completely radiographed in a single exposure and all parts of the image were comparable to that shown in the figure. A thin section of graphite is shown in Fig. 4. Both pores and highdensity inclusions are readily evident. Figure 5 is a composite of several microradiographs of different types of paper showing the varied fibrous structure. The 500X microradiograph, Fig. 6, of a particle of diatomaceous earth reveals the very fine detail of the cellular structure.

\section{CONCLUSIONS}

The contact microradiographic technique which has been studied has proven a very useful tool for the nondestructive evaluation of very small specimens or small details in larger, thin sections. The removal of extraneous absorbers, such as the air atmosphere and the film holder, allows the use of lower energies and therefore higher contrast microradiographs. Included among the subjects at ORNL have been coated uranium carbide fuel particles, fine mesh screen, graphite, and beryllium, as well 


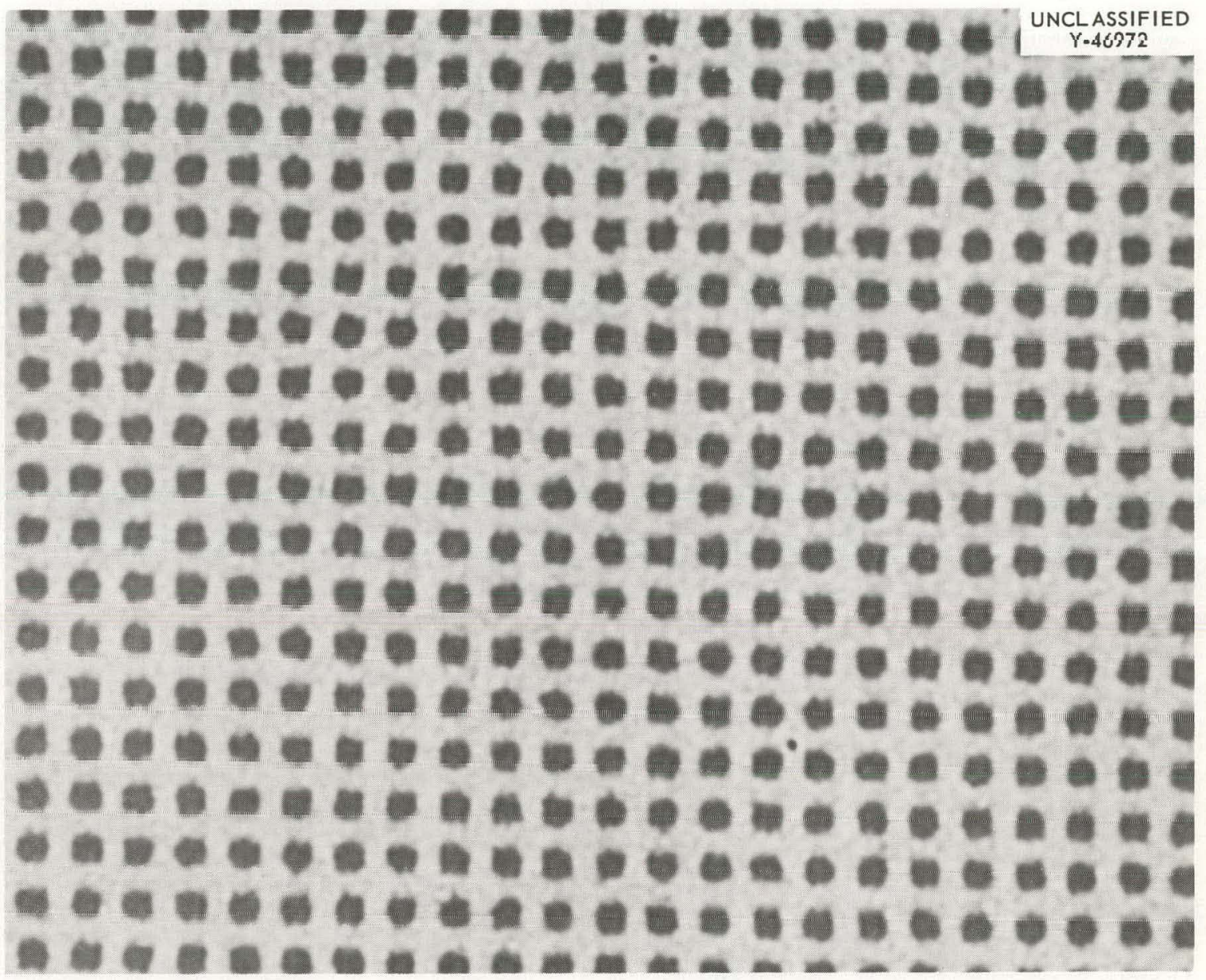

Fig. 3. Microradiograph of 2000-Mesh Nickel Screen. 500X. 


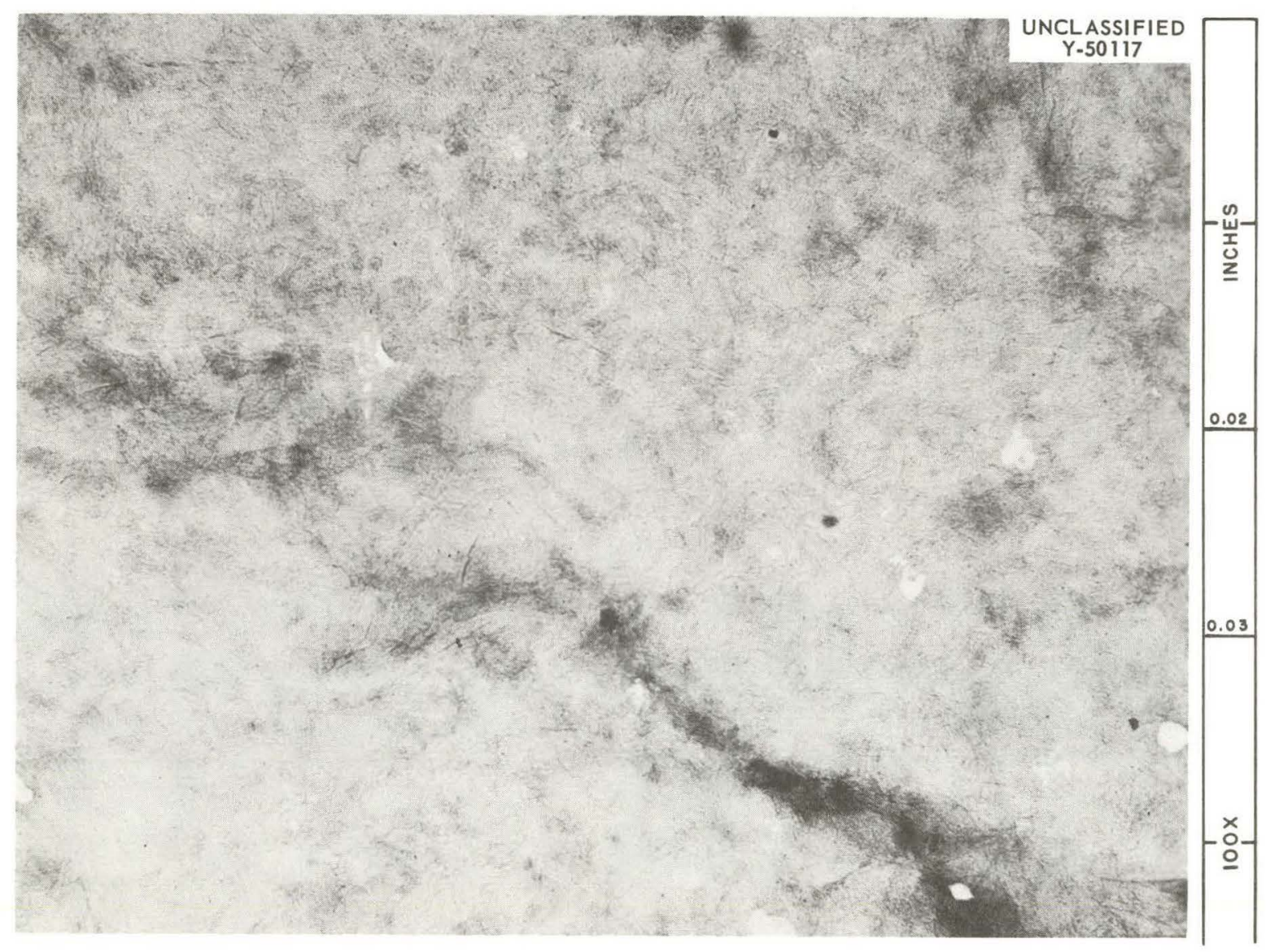

Fig. 4. Section of Graphite 0.040-in. Thick. I00X. 


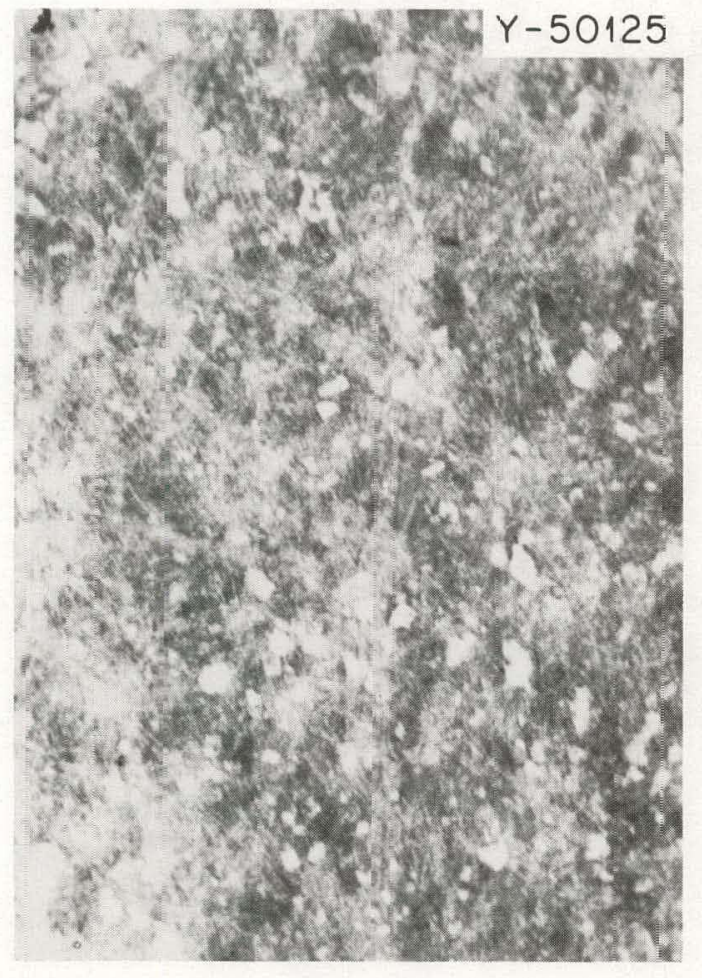

NOTE PAPER

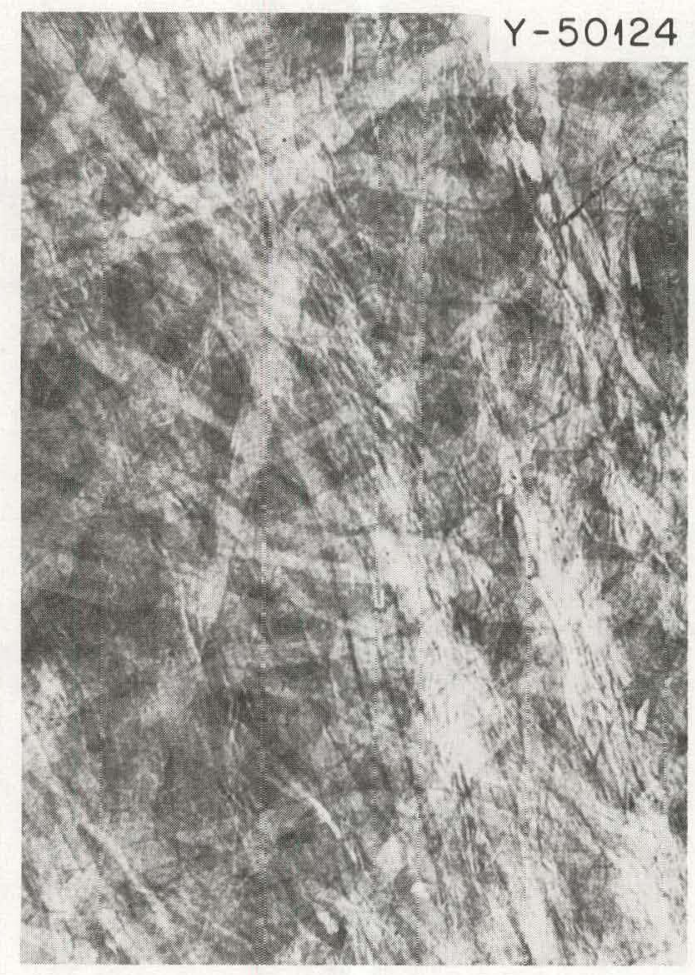

PAPER TOWEL

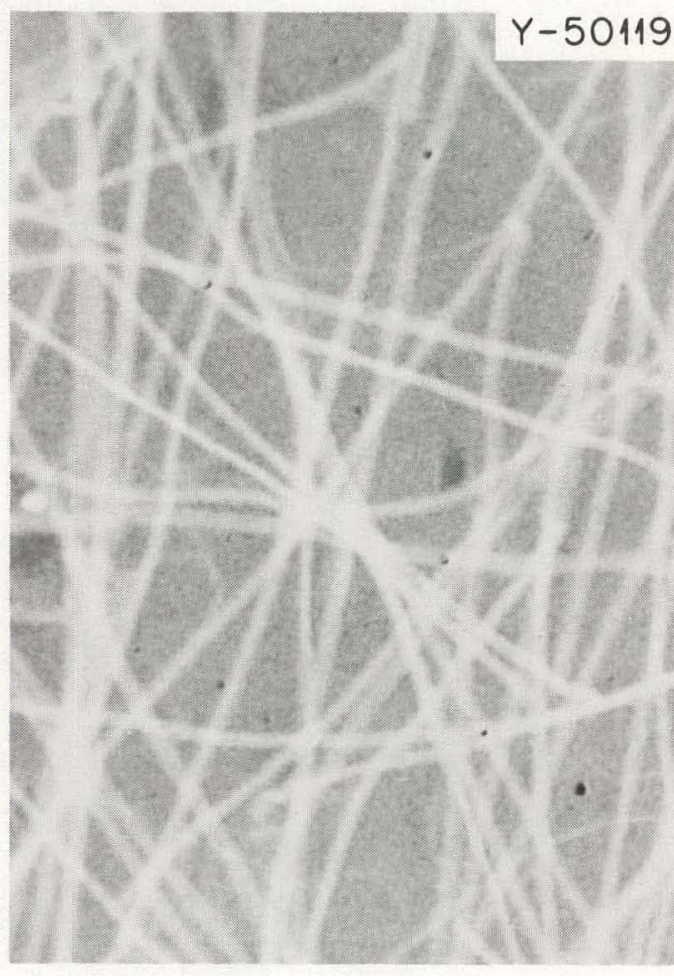

LENS TISSUE

Fig. 5. Microradiographs of Various Papers. 100X. Reduced 7\%. 


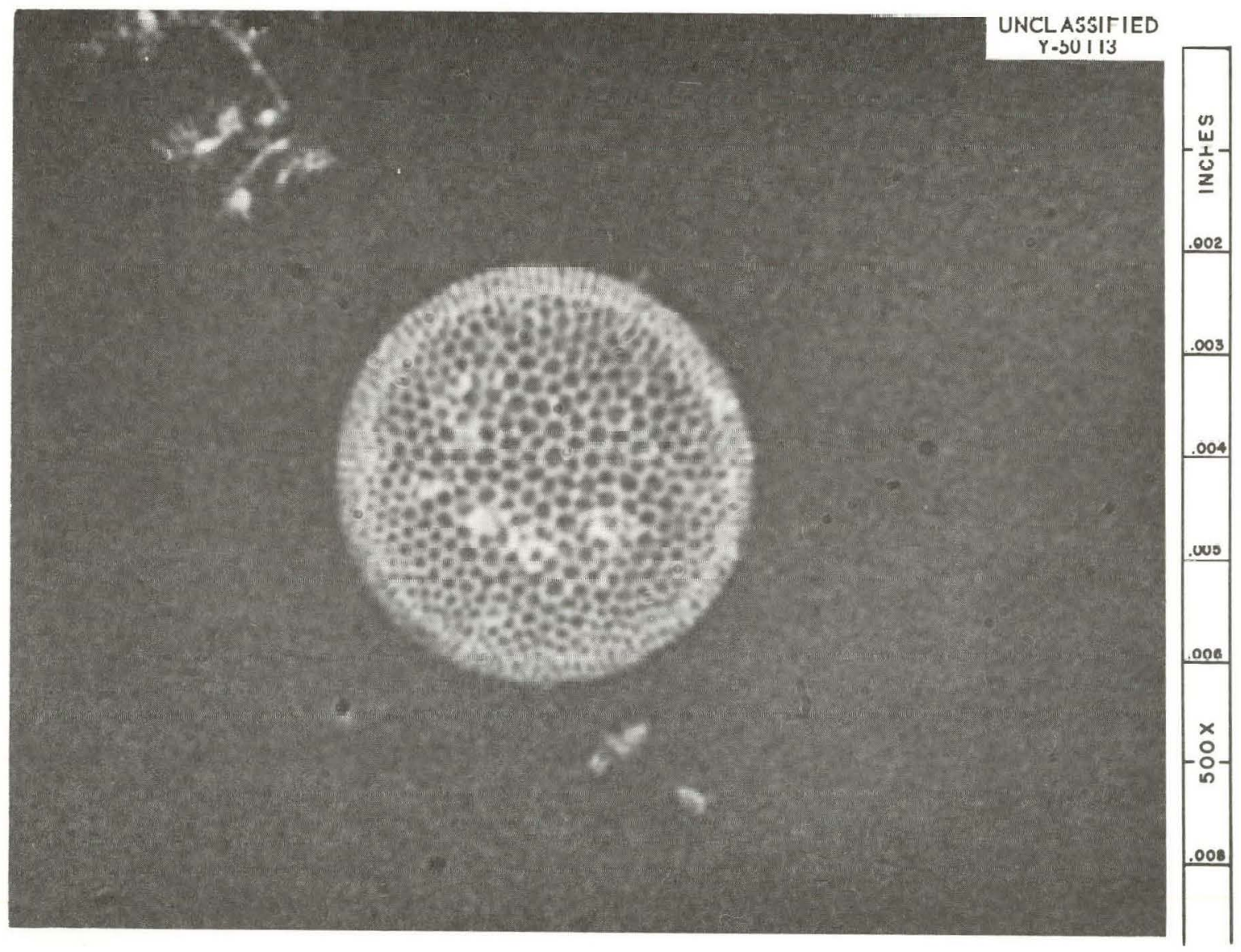

Fig. 6. Cellular Structure of Diatomaceous Earth. 500X. 
as subjects of academic interest such as paper, wood, or other fibrous materials. As additional recognition is given to this valuable inspection technique, many other uses will be conceived.

\section{REFERENCES}

1. Arne Engstrom, "Historadiography," Chap. 10 in Physical Techniques in Biological Research Vol III, pp 489-544, Academic Press, New York, 1956.

2. V. E. Coslett and W. C. Nixon, X-Ray Microscopy, Cambridge University Press, 1960.

3. R. W. McClung, "Techniques for Low Voltage Radiography," Nondestructive Testing $\underline{\underline{20}}(4), 248-253$,' July-August 1962.

4. D. E. Lea, Actions of Radiations on Living Cells, p 24, Cambridge University Press, 1947.

5. "Coated Particle Fuels - Promise and Problems," Nucleonics 21, 96-98, (March 1961).

6. J. H. Oxley, M. F. Browning, N. D. Viegel, and J. M. Blocher, Jr., "Microminiaturized Fuel Elements by Vapor-Deposition Techniques," Ind. Eng. Chem. Prod. Res. Develop. I('), LU'L-1U'/ (June 1962). 


\section{THIS PAGE}

\section{WAS INTENTIONALLY \\ LEFT BLANK}


ORNL-35II

UC-25 - Metals, Ceramics, and Materials
TID-4500 (22nd ed.)

\section{INIEERAL DISTRIBUTION}

1-3. Central Research Library

4. Reactor Division Library

5-6. ORNL - Y-12 Technical Library

7-16. Laboratory Records Department

17. Laboratory Records, ORNL R.C.

18. ORNL Patent Office

19. R. L. Beatty

20. C. M. Blood

21. E. S. Bomar

22. W. E. Browning

23. R. S. Crouse

24. D. R. Cuneo

25. D. A. Douglas

26. H. W. Dunn

27. B. R. Fish

28. J. H Frye, Jr.

29. R. J. Gray

30. D. M. Hewette, II

31-35. M. R. Hill

36. T. M. Kegley, Jr.

37. R. H. Lafferty, Jr.

38. C. E. Larson

39. T. S. Lundy

40. A. P. Malinauskas

41. H. G. MacPherson
42-107. W. D. Manly

108-112. R. W. McClung

113. H. E. MeCoy

114. M. F. Osborne

115. M. L. Picklesimer

116. J. J. Pinajian

117. S. A. Rabin

118. R. E. Reed

119. M. W. Rosenthal

120. G. Samuels

121. R. L. Senn

122. R. L. Sherman

123. R. P. Shields

124. O. Sisman

125. G. M. Slaughter

126. W. J. Stelzman

127. J. A. Swartout

128. W. C. Thurber

129. G. M. 'Tolson

130. D. B. Trauger

131. A. M. Weinberg

132. A. A. Burr (consultant)

133. J. R. Johnson (consultant)

134. C. S. Smith (consultant)

135. R. Smoluchowski (consultant)

EXTERRIAL DISTRIBUTION

136. C. M. Adams, Jr., MIT

137-138. D. F. Cope, ORO

139. Research and Development, ORO

140. D. E. Baker, GR Hanford

141.. Ersel Evans, GE Hanford

142. J. L. Gregg, Cornell University

143. J. Simmons, AEC, Washington

144. E. E. Stansbury, University of Tennessee

145. Donald K. Stevens, AEC, Washington

146-656. Given distribution as shown in TID-4500 (22nd ed.) under Metals, Ceramics, and Materials category 